\title{
Implementation of Fiduciary Registration According to Finance Ministry, Police, and Financial Services Authority (OJK)
}

\author{
Suwinto Johan* \\ Management Department, Faculty of Business, President University \\ Jababeka Education Park, Jl. Ki Hajar Dewantara, Kota Jababeka, Cikarang Baru, Bekasi 17550, Indonesia \\ suwintojohan@gmail.com
}

Received: $15^{\text {th }}$ February 2021/ Revised: 22 ${ }^{\text {nd }}$ April 2021/ Accepted: $22^{\text {nd }}$ April 2021

\begin{abstract}
How to Cite: Johan, S. (2021). Implementation of fiduciary registration according to finance ministry, police, and Financial Services Authority (OJK). The Winners, 22(2), 183-189. https://doi.org/10.21512/tw.v22i2.7064
\end{abstract}

\begin{abstract}
Theresearch aimed to find outfiduciary guarantees registration from a legal perspective, especially the executive or administrative regulations. The research examined the existing regulations and laws by analysing primary and secondary data using normative juridical methods. The research concludes that the fiduciary registration obligations stipulated in the Regulation of Minister of Finance (PMK) Number 130/PMK.010/2012 are not in synchronic with the Financial Services Authority Regulation (POJK) Number 29/POJK.05/2014, which is replaced by the Financial Services Authority Regulation Number 35/POJK.05/2018. Revocation of Regulation of Minister of Finance Number 130/PMK.010/ 2012 by Regulation of the Minister of Finance Number 23/ PMK.010/2017 is not accompanied by amendments to the Regulation of the Republic of Indonesia National Police Number 8 of 2011. The loan agreement remains valid if it fulfills the principles of the agreement. It is suggested that relevant institutions, particularly the Financial Services Authority (OJK) as the financial industry supervisor, take initiatives to synchronize all regulations for the implementation of fiduciary registration.
\end{abstract}

Keywords: fiduciary registration, finance ministry, police, Financial Services Authority (OJK)

\section{INTRODUCTION}

The 1998 economic crisis has brought many changes, especially in the legal system in Indonesia. The banking industry encountered a crisis, in which banks experienced difficulties executing collateral since the guarantees provided could also be pledged to several parties (double or triple pledged). Banking supervision by regulators is not strict (Kartini, 2016). The provision of credit with guarantees, especially guarantees of the movable good or property, has not been regulated concretely in Indonesia's legal system before 1999. A fiduciary guarantee institution is a form of guarantee originated from jurisdiction which has become a concrete legal route confirmed in Law Number 42 of 1999 on Fiduciary Guarantee. The purpose of the Fiduciary Guarantee Law (UU JF) is to provide legal protection to parties and legal certainty to credit providers (Akhsin \& Mashdurahatun, 2017). One of the credit collaterals for movable goods or objects is a motor vehicle (Kumaladewi, 2015).

The fiduciary is the transfer of rights of a tangible or intangible movable object by the fiduciary or object's owner to another party, where the object is still used or controlled by the fiduciary or the owner. Fiduciary security is a security right over tangible or intangible movable objects exercised by the fiduciary or the object's owner, where the control of the goods remains with the fiduciary. The giver of the fiduciary is the owner of objects of fiduciary guarantee. A fiduciary is a person or company that has receivables whose payment is guaranteed by fiduciary collateral objects. Fiduciary recipients are banks and non-bank financial institutions such as financing or leasing companies. These definitions are deduced from Law Number 42 of 1999 on Fiduciary Security.

Based on the Regulation of the Financial Services Authority (Peraturan Otoritas Jasa Keuangan/ POJK) Number 35/POJK.05/2018 on the Operation of a Financing Company, financing company is a business entity or company engaged in the financing of goods and/or services. Financing companies may carry out three main types of financing: 1) working capital financing, 2) investment financing, and 3) multipurpose financing. Multipurpose financing is the 
financing of goods and services required by the debtor for use or consumption and not for business purposes or productive activities within the agreed period.

The distribution of multipurpose financing under collateral for movable goods is the main activity of the financing industry. Movable goods financed are 4-wheeled vehicles, 2-wheeled vehicles, and another consumer financing, such as refrigerators, televisions, and other home appliances. There is a condition in which the debtor remains using these goods, and the rights to the goods are granted to the financing company with a fiduciary guarantee.

The implementation of fiduciary security registration has faced several obstacles since the Fiduciary Guarantee Law was issued in 1999. In the early stages of implementation, fiduciary offices were not yet established across Indonesia. The fiduciary office was only available in Jakarta. On the other hand, finance companies have financing networks throughout Indonesia. Finance companies have difficulty applying for fiduciary guarantees at an early stage. Fiduciary guarantee must be registered at the Fiduciary Registration Office by issuing a fiduciary certificate (Nasution \& Limbong, 2019). Fiduciary guarantees aim to reduce the risk of credit provided by lending institutions. This guarantee is an additional guarantee to secure the repayment that have been given or loan funds provided by finance companies or banks (Setiono, Sulistyo, \& Widayati, 2021).

Registration of Fiduciary Guarantee is subject to fees. Processing fees include insurance fees, administrative fees, survey fees, stamp fees, insurance fees, and other costs, such as fiduciary security registration fees. In general, financing companies charge fiduciary security registration fees to borrowers, consumers, or debtors since they do not cover it.

The police arrests several board of management of financing companies for failing to carry out fiduciary guarantee registration. Police suspects that leaders of financing companies have imposed fiduciary fees on consumers or their debtors, but do not register fiduciaries (Tobing, 2013). Financing companies that have received payment of a fiduciary registration fee and do not register may be subject to suspicion of embezzlement of funds (Ulum, 2013), which is a fiduciary guarantee registration fee.

Fiduciary security registration has experienced several technical and non-technical challenges. The unclear implementation of fiduciary guarantees' registration has shown that the preparation for the implementation of fiduciary was not well-coordinated between institutions when it launched. The fiduciary guarantee has executorial power. When a debtor experiences a default, the creditor can execute objects that become fiduciary guarantees without going through a judicial process. The creditor has the authority to carry out the parate executie of the fiduciary security object (Dewi, Saptanti, \& Purwadi, 2017). Registration of fiduciary security is essential since it is related to material rights that possess droit de suite characteristics, droit de preference, specialty, and publicity (Rufaida \& Sacipto, 2019). Execution of guarantees with the title executorial creditor can be executed directly through a public auction without going through a court. Underhand sales can be made based on an agreement between the giver and recipient of the fiduciary guarantee (Hapsari \& Mulyoto, 2017). On Article 30 of the Fiduciary Guarantee Law, the creditor has been granted the right to repossess with the executorial title to take the fiduciary guarantee object directly (Heriawanto, 2019). According to the Fiduciary Guarantee Law, a takeover of a motorized vehicle can be done directly if it is the fiduciary security object of a debtor who has defaulted (Ramadhanneswari, Suharto, \& Saptono, 2017).

At the end of 2019, the Constitutional Court issued a Constitutional Court Decision (Putusan Mahkamah Konstitusi/PMK) Number 18/PUUXVII/2019, which states that according to Article 15 paragraph (2) of Law Number 42 of 1999 on Fiduciary Guarantee, as long as the phrase "executorial power" and the phrase "equal to a court decision that has permanent legal force" are contrary to the 1945 Constitution of the Republic of Indonesia, they do not have binding legal force as long as they are not interpreted as fiduciary guarantees, where there is no agreement on default. The debtor objects to voluntarily hand over the object that is pledged as the guarantee of fiduciary. All legal mechanisms and procedures in the Fiduciary Guarantee Certificate's execution must be implemented and applied in the same way as a court execution decision that has permanent legal force.

The Constitutional Court Decision also states that according to Article 15 paragraph (3) of Law Number 42 of 1999 on Fiduciary Security, as long as the phrase "default of promise" is contrary to the 1945 Constitution of the Republic of Indonesia, it has no binding legal force as long as it does not mean that "the existence of a default is not determined unilaterally by the creditor, but based on an agreement between the creditor and the debtor or based on legal remedies which determine that the default has occurred".

The Constitutional Court Decision states that according to Article 15 paragraph (2) of Law Number 42 of 1999 on Fiduciary Guarantee, as long as the phrase "executorial power" is contrary to the 1945 Constitution of the Republic of Indonesia, it does not have binding legal force as long as it is not interpreted as a fiduciary guarantee, where there is no agreement regarding default. The debtor objected to voluntarily hand over the object, which is a fiduciary guarantee. All legal mechanisms and procedures in the Fiduciary Guarantee Certificate's execution must be carried out and applied in the same manner as a court execution decision that has permanent legal force. Fiduciary security execution is an activity to confiscate and sell objects that are the objects of fiduciary Security (Nusantara \& Wirasila, 2018). The fiduciary guarantee agreement provides creditors with weak legal protection. Legal protection for creditors can be reinforced by establishing a guarantee execution agency and socialization on fiduciary implementation 
(Winarno, 2013).

Research on fiduciary guarantee is rarely conducted thoroughly. Research on fiduciary guarantee since the issuance of the Law in 1999, which connects the Fiduciary Guarantee Law with implementing regulations, especially those related to the financing industry, is still rare. The research provides benefits for the financing industry and financing law practitioners in conducting their business activities connected with fiduciary guarantees.

The Fiduciary Guarantee Deed must be done in an authentic form. An authentic deed must be done based on Article 1868 of the Civil Code, where one of the conditions is that it must be made by and before a notary (Suharto, 2017). A fiduciary guarantee agreement that is not made in a notary deed or is not registered remains an agreement that binds the parties as long as the agreement has fulfilled the principles based on the Criminal Code Article 1320 provisions Article 1338 regarding the principle of Pacta Sunt Servada. This agreement remains a valid agreement (Huru, 2019). Fiduciary registration still has several obstacles, namely fiduciare eigendom overdracht, deliberate acts against the Law by one of the parties, and the guarantee given remains in the guarantor's control, so the fiduciary recipient will have difficulty executing (Paparang, 2014). The transfer of fiduciary items by the fiduciary may be subject to criminal penalties. This can be excluded if the fiduciary has paid off the debt to the fiduciary (Sriono, 2019).

The research has four questions: How are the regulations changed for fiduciary security registration from the Ministry of Finance to the Financial Services Authority regulation?; Is every disbursement of financing with a movable property guarantee must be registered for fiduciary Security?; Can the financing company charge an administration fee to the debtor without registering for fiduciary Security according to the underlying law and regulations?; Can financing companies carry out consumer financing without registering a fiduciary guarantee according to the underlying law and regulations?

\section{METHODS}

The research applies a normative juridical method to examine the existing laws and regulations in Indonesia. The research analyzes primary and secondary data. Primary data are information on the board of directors' positions directly obtained from the field. Secondary data is the current laws and regulations.

The research begins with collecting materials related to legal matters with material identification procedures related to the research topic and an inventory of materials related to the research topic. The material inventory consists of primary legal materials, secondary legal materials, and tertiary legal materials. Primary legal materials are legal materials consisting of laws and regulations in Indonesia.
Secondary legal materials are used to explain the primary legal materials, such as books, reports, and others. Tertiary legal materials are legal materials that serve as secondary guidance, such as additional information and data related to research topics sourced from the internet (Johan \& Ariawan, 2020).

\section{RESULTS AND DISCUSSIONS}

The Fiduciary Guarantee Law's implementation has undergone several changes in line with changes in the relevant authorities. It results in a change in the fiduciary guarantee registration process. The Regulation of the Chief of Police of the Republic of Indonesia is a regulation that regulates the procedure for the execution of collateral with the fiduciary guarantee, which is summarized in Table 1 with the other regulations. Furthermore, there is a Regulation of the Minister of Finance of the Republic of Indonesia (Peraturan Menteri Keuangan/PMK) Number 130 of 2012 on The Obligation to Register Fiduciary for Motor Vehicle Financing. This regulation creates uncertainty over special regulations regarding motorized vehicles only. Movable goods are not only motorized vehicles, but this regulation explicitly regulates the obligation to register motor vehicles.

In 2014, the Financial Services Authority of the Republic of Indonesia (Otoritas Jasa Keuangan/OJK) issued Regulation of Financial Services Authority of the Republic of Indonesia Number 29 of 2014, which regulates that fiduciary is one way of mitigating risk. In financing business, it is not required to register a fiduciary guarantee, especially for motorized vehicles. This is different from Regulation of the Minister of Finance of the Republic of Indonesia Number 130 of 2012. Regulation of the Minister of Finance of the Republic of Indonesia Number 23 of 2017 revokes Regulation of the Republic of Indonesia Number 130 of 2012. For approximately five years, the financial industry continues to carry out fiduciary registration as regulated in Regulation of the Minister of Finance Number 130. The inconsistency between Regulation of Financial Services Authority and Regulation of the Minister of Finance creates legal uncertainty, even though the supervision of the financing industry has shifted from Capital Market and Financial Services Supervisory Institution (Bapepam LK) under the Ministry of Finance to the Financial Services Authority (OJK) per Law Number 21 of 2011 on the Financial Services Authority.

Regulation of Financial Services Authority of the Republic of Indonesia Number 35 of 2018 reaffirms that fiduciary security registration is a form of risk mitigation. Registration of fiduciary security is not an obligation for motor vehicle financing. To execute the guarantee, the finance company is required to have a fiduciary certificate. However, Hapsari and Mulyoto (2017) state that underhand sales of collateral must be made based on the fiduciary guarantee agreement. The fiduciary guarantee is an additional to the repayment of 
Table 1 Summary Regulation

\begin{tabular}{|c|c|c|c|c|}
\hline $\begin{array}{l}\text { Regulation of the } \\
\text { Chief of Police of } \\
\text { the Republic of } \\
\text { Indonesia Number } 8 \\
\text { Year } 2011\end{array}$ & $\begin{array}{l}\text { Regulation of the } \\
\text { Minister of Finance } \\
\text { of the Republic of } \\
\text { Indonesia Number } \\
\text { 130/PMK.010/2012 }\end{array}$ & $\begin{array}{l}\text { Regulation of Financial } \\
\text { Services Authority } \\
\text { of the Republic of } \\
\text { Indonesia Number 29/ } \\
\text { POJK.05/2014 }\end{array}$ & $\begin{array}{l}\text { Regulation of } \\
\text { the Minister } \\
\text { of Finance of } \\
\text { the Republic of } \\
\text { Indonesia Number } \\
\text { 23/PMK.010/2017 }\end{array}$ & $\begin{array}{l}\text { Regulation of } \\
\text { Financial Services } \\
\text { Authority of } \\
\text { the Republic of } \\
\text { Indonesia Number } \\
\text { 35/POJK.05/2018 }\end{array}$ \\
\hline $\begin{array}{l}\text { Security against } \\
\text { the object of the } \\
\text { fiduciary guarantee } \\
\text { can be carried out } \\
\text { with the following } \\
\text { requirements: there } \\
\text { is a request from } \\
\text { the applicant, has a } \\
\text { fiduciary guarantee } \\
\text { certificate, registered } \\
\text { fiduciary security } \\
\text { at the fiduciary } \\
\text { registration office, } \\
\text { has a fiduciary } \\
\text { guarantee certificate } \\
\text { and fiduciary } \\
\text { guarantee is in the } \\
\text { territory of Indonesia }\end{array}$ & $\begin{array}{l}\text { Financing companies } \\
\text { that provide financing } \\
\text { for motor vehicles } \\
\text { must register } \\
\text { fiduciary security } \\
\text { at the Fiduciary } \\
\text { Registration Office. } \\
\text { Registration is obliged } \\
\text { to register a fiduciary } \\
\text { guarantee no later } \\
\text { than } 30 \text { calendar days. } \\
\text { Financing companies } \\
\text { are prohibited from } \\
\text { withdrawing fiduciary } \\
\text { objects in the form of } \\
\text { motorized vehicles if } \\
\text { there is no fiduciary } \\
\text { guarantee certificate. }\end{array}$ & $\begin{array}{l}\text { Details of costs related } \\
\text { to financing provided } \\
\text { must contain at least } \\
\text { insurance/guarantee/ } \\
\text { fiduciary costs. An } \\
\text { explicit clause of } \\
\text { fiduciary security if } \\
\text { there is an imposition of } \\
\text { fiduciary security. One } \\
\text { way to mitigate risks } \\
\text { is to charge fiduciary } \\
\text { security on financed } \\
\text { goods or goods that } \\
\text { become collateral for } \\
\text { financing activities. } \\
\text { Financing companies } \\
\text { that carry out financing } \\
\text { by imposing fiduciary } \\
\text { security must register at } \\
\text { the fiduciary registration } \\
\text { office. The obligation } \\
\text { to register fiduciary } \\
\text { security applies to } \\
\text { financing originating } \\
\text { from follow-up financing } \\
\text { and co-financing. } \\
\text { Financing companies } \\
\text { are required to register } \\
\text { no later than one month. } \\
\text { Financing companies } \\
\text { are prohibited from } \\
\text { executing collateral if } \\
\text { there is no fiduciary } \\
\text { guarantee certificate. The } \\
\text { execution of fiduciary } \\
\text { guarantees must meet } \\
\text { the provisions and } \\
\text { requirements of the } \\
\text { Law regarding fiduciary } \\
\text { security and have been } \\
\text { agreed upon by the } \\
\text { parties. } \\
\text { Administrative sanctions } \\
\text { for fiduciary still apply } \\
\text { based on Regulation of } \\
\text { the Minister of Finance } \\
\text { of the Republic of } \\
\text { Indonesia Number } 130 / \\
\text { PMK.010/2012 }\end{array}$ & $\begin{array}{l}\text { Revocation of } \\
\text { Regulation of } \\
\text { the Minister of } \\
\text { Finance/Decree } \\
\text { of the Minister of } \\
\text { Finance whose } \\
\text { regulatory authority } \\
\text { is transferred } \\
\text { from the Ministry } \\
\text { of Finance to } \\
\text { the Financial } \\
\text { Services Authority, } \\
\text { including } \\
\text { regulation of the } \\
\text { Minister of Finance } \\
\text { of the Republic of } \\
\text { Indonesia Number } \\
\text { 130/PMK.010/2012 } \\
\text { on Registration } \\
\text { of Fiduciary } \\
\text { Guarantee } \\
\text { for Financing } \\
\text { Companies } \\
\text { Conducting } \\
\text { Financing for } \\
\text { Motor Vehicles } \\
\text { with Fiduciary } \\
\text { Guarantee } \\
\text { Imposition }\end{array}$ & $\begin{array}{l}\text { Financing companies } \\
\text { are required to } \\
\text { mitigate financing } \\
\text { risks. } \\
\text { One way to mitigate } \\
\text { risks is to charge } \\
\text { fiduciary Security } \\
\text { for collateral from } \\
\text { financing activities. } \\
\text { Financing companies } \\
\text { that mitigate risks by } \\
\text { imposing fiduciary } \\
\text { security must register } \\
\text { fiduciary guarantees } \\
\text { at the fiduciary } \\
\text { registration office. }\end{array}$ \\
\hline
\end{tabular}

Source: Research Results

loan provided by finance companies or banks (Setiono et al., 2021).

Nowadays, financing companies still experience uncertainty in doing business. The execution of the fiduciary guarantee must have a fiduciary guarantee certificate. If there is no fiduciary certificate, the business actor is prohibited from executing it. On the other hand, after the issuance of the Constitutional 
Court Decision of the Republic of Indonesia Number 18/ PUU-XVII/2019, the execution of the fiduciary guarantee experiences uncertainty once more. Since Regulation of the Minister of Finance of the Republic of Indonesia Number 18 of 2019 has emphasized that Article 15 must go through a court process or obtain an agreement of default by both parties.

The number of implementing regulations from various agencies has resulted in uncertainty regarding the implementation of fiduciary guarantees by nonbank financial institutions, especially the financing industry. The objective of the Fiduciary Guarantee Law is to provide legal certainty. The implementation of the Fiduciary Guarantee Law and implementing regulations creates uncertainty for businesses.

The implementation of fiduciary security registration must be restructured by all related parties, especially Financial Services Authority. The implementing regulations involve businesses, also for industries other than the financial industry, notary, and banking.

In accordance with Regulation of Financial Services Authority of the Republic of Indonesia Number 35 of 2018, financing companies are not required to register for fiduciary Security. Registration of fiduciary Security is one of three ways to mitigate risks as stated in Regulation of Financial Services Authority of the Republic of Indonesia Number 35 of 2018. This is different from Regulation of the Minister of Finance of the Republic of Indonesia Number 130 of 2012.

However, to carry out the execution of a fiduciary guarantee, a financing company requires registration of a fiduciary guarantee. This is in accordance with the Decree of the National Police Chief and Regulation of Financial Services Authority of the Republic of Indonesia Number 35 of 2018 that to carry out the execution of fiduciary guarantees requires a fiduciary certificate. A fiduciary certificate will be issued by the fiduciary registration agency. In addition to a fiduciary certificate, a finance company requires a debtor's default condition and a warning letter or subpoena that has been given by the financing company to the debtor.

In accordance with the Decision of the Constitutional Court of the Republic of Indonesia Number 18/PUU-XVII/2019, the financing company needs approval from the debtor to take over the collateral, if not through a court decision. In practice, many finance companies can make a statement signed by the debtor, stating that the debtor is willing to hand over the vehicle or collateral, if there has been a default.

The regulation regarding the fiduciary registration fee has been mentioned as the guarantee fee in Regulation of Financial Services Authority of the Republic of Indonesia Number 35 of 2018. This is different from Regulation of Financial Services Authority of the Republic of Indonesia Number 29 of 2014 which mentions the fiduciary registration fee. Regulation of Financial Services Authority of the Republic of Indonesia Number 35 of 2018 states that the guarantee fee includes the fiduciary registration fee with additional note if required. According to Ulum (2013), if a finance company has obtained the fee for fiduciary registration from customer, then the finance company must register it according to the underlying regulations.

However, when it comes to the fiduciary registration fee for the financing company, the financing company must register with the related institution. Sometimes financing companies do not explain in detail about the registration fee for fiduciary security. The financing company only mentions administrative costs. The violates Regulation of Financial Services Authority Number 35 of 2018. Registration fee for fiduciary security must be specified with an explanation, at least as the fiduciary guarantee fee. This explanation is important not to cause any legal uncertainty.

On the contrary, if the financing company does not charge a fiduciary registration fee, the finance company does not have a fiduciary registration obligation. The obligation of fiduciary registration becomes an additional obligation on the financing company. If the financing company does not charge fees, it does not carry out fiduciary registration obligation. This could be a financing company's promotion strategy by granting fiduciary security fee registration exemptions.

Financing companies can carry out consumer financing without conducting fiduciary registration. However, finance companies are not allowed to execute collateral. Does this multipurpose financing still meet the terms of an agreement? If it is based on agreement principles, the financing agreement remains binding on the parties. This financing agreement can be executed for guarantee execution or collateral takeover, must be through a court decision. This can be done if there is default. Conversely, what if the debtor voluntarily hands over collateral?

It will be difficult to distinguish between expropriation and voluntary surrender of collateral. Takeover can be done by signing the minute of delivery of the vehicle or vice versa, the execution of the guarantee without a certificate of guarantee is also accompanied by an official report on the handover of the vehicle. In written evidence, the debtor has submitted the vehicle. Based on the Fiduciary Guarantee Law, repossessed of a vehicle that already has the defaulted fiduciary security registration can be made directly (Ramadhanneswari et al., 2017).

In addition, financing companies can take steps by using a working capital financing scenario or leasing financing. Leasing does not have to go through fiduciary registration. However, leasing is the financing of production equipment.

In fact, the micro, small, and medium enterprises (MSME) sector experiences difficulties in distinguishing the differences in the means of production. A businessman who owns a small shop uses a vehicle for both business and family transportation. One of the differences in this respect is the taxation of 
lease payments.

The financing industry and other financial institutions must determine strategies for lending. This strategy will determine the risk mitigation strategy. One way of mitigating risk is to be able to execute collateral to settle unpaid loans. In addition, financing business must have standard operating procedures in handling defaulted consumers.

Regulators need to coordinate the regulations for implementing this fiduciary guarantee. Regulatory coordination must be able to achieve synchronization between government agencies. The regulations for implementing fiduciary security must socialize to the public. The drafting of executive regulations involves related professions, such as notaries and debt collection companies.

\section{CONCLUSIONS}

The Fiduciary Guarantee Law provides legal certainty for businesses, especially for financial institutions in providing loans. The Fiduciary Guarantee Law and its executive regulations create legal uncertainty for busineses. This has resulted in different interpretations among businesses, especially regarding the registration obligation for fiduciary security for defaulters, the obligation to register fiduciary security for collateral for movable property or good, and the process and requirements for executing fiduciary goods collateral. The fiduciary registration regulations aim to protect the interests of debtors and creditors. Fiduciary registration will provide legal certainty, in the event of a dispute.

It is suggested that relevant institutions synchronize all regulations for the implementation of fiduciary registration. Therefore, the Financial Services Authority (OJK), as the financial industry supervisor, needs to take initiatives regarding this matter. Finally, the existing regulations must provide legal certainty for all parties, both debtors and creditors.

\section{REFERENCES}

Akhsin, H. M. \& Mashdurahatun, A. (2017). Akibat hukum jaminan fidusia yang tidak didaftarkan menurut UU Nomor 42 Tahun 1999. Jurnal Akta, 4(3), 485-500.

Decision of Constitutional Court of the Republic of Indonesia (Putusan Mahkamah Konstitusi) Number 18/PUU-XVII/2019 on Fiduciary Guarantee

Dewi, R. P., Saptanti, N., \& Purwadi, H. (2017). Kekuatan eksekutorial sertifikat jaminan fidusia berdasarkan Undang Undang Nomor 42 tahun 1999 tentang Jaminan Fidusia. Jurnal Repertorium, 4(1), 73-81.

Hapsari, I. K. \& Mulyoto. (2017). Kajian yuridis eksekusi obyek jaminan fidusia yang dialihkan kepada pihak ketiga. Jurnal Repetorium, 4(1), 45-51.

Heriawanto, B. K. (2019). Pelaksanaan eksekusi objek jaminan fidusia berdasarkan title eksekutorial. Legality: Jurnal Ilmiah Hukum, 27(1), 54-67. https:// doi.org/10.22219/jihl.v27i1.8958.

Huru, F. F. (2019). Kedudukan hukum akta jaminan fidusia yang tidak didaftarkan. Jurtama, 1(1), 46-57. https:// doi.org/10.31090/jurtama.v1i1.804.

Johan, S. \& Ariawan, A. (2020). Pertanggungjawaban direksi setelah pemberian acquit and discharge. Acta Comitas Jurnal Hukum Kenotariatan, 5(3), 586600. https://doi.org/10.22437/ujh.3.1.107-137.

Kartini, D. (2016, 09 August). Perbankan dalam pusaran krisis moneter 1997-1998. Liputan Khusus Perbankan. https://lipsus.kontan.co.id/v2/ perbankan/read/320/perbankan-dalam-pusarankrisis-moneter

Kumaladewi, N. A. (2015). Eksekusi kendaraan bermotor sebagai jaminan fidusia yang berada pada pihak ketiga. Jurnal Repertorium, 2(2), 60-69.

Law of the Republic of Indonesia Number 42 of 1999 on Fiduciary Security

Nasution, A. \& Limbong, F. S. (2019). Tinjauan yuridis atas pelaksanaan jaminan fidusia. Seminar Hasil Penelitian 2019, 1-10.

Nusantara, N. P. T. P. \& Wirasila, A. A. N. (2018). Eksekusi dan pendaftaran objek jaminan fidusia berdasarkan Undang - Undang Nomor 42 tahun 1999 tentang Jaminan Fidusia. Kertha Semaya: Jurnal Ilmu Hukum, 2(2), 1-5. https://ojs.unud.ac.id/index.php/ kerthasemaya/article/view/38517.

Paparang, F. (2014). Implementasi jaminan fidusia dalam pemberian kredit di Indonesia. Jurnal LPPM Bidang EkoSosBudKUm, 1(2), 56-70.

Ramadhanneswari, S., Suharto, R., \& Saptono, H. (2017). Penarikan kendaraan bermotor oleh perusahaan pembiayaan terhadap debitur yang mengalami kredit macet (wanprestasi) dengan jaminan fidusia ditinjau dari aspek yuridis. Diponegoro Law Journal, 6(2), $1-13$.

Regulation of Financial Services Authority of the Republic of Indonesia (POJK) Number 35/POJK.05/2018 on the Operation of a Finance Company

Regulation of Financial Services Authority of the Republic of Indonesia (POJK) Number 29/POJK.05/2014 on the Operation of a Finance Company

Regulation of the Head of the National Police of the Republic of Indonesia Number 8 of 2011 on Safeguarding the Execution of Fiduciary Security

Regulation of the Minister of Finance of the Republic of Indonesia (PMK) Number 130/PMK.010/2012 on the Registration of Fiduciary Guarantee for Financing Companies Conducting Consumer Financing for Motor Vehicles with Fiduciary Guarantee Imposition

Regulation of the Minister of Finance of the Republic of Indonesia (PMK) Number 23/PMK.010/2017 on the Revocation of the Regulation of The Minister of Finance/Decision on the Finance Material which Has Been Transferred from the Ministry of Finance to the Financial Services Authority

Rufaida, K. K. \& Sacipto, R. (2019). Tinjauan hukum terhadap eksekusi objek jaminan fidusia tanpa titel eksekutorial yang sah. Refleksi Hukum: Jurnal Ilmu Hukum, 4(1), 21-40. https://doi.org/10.24246/ jrh.2019.v4.i1.p21-40. 
Setiono, G. C., Sulistyo, H., \& Widayati, S. C. (2021). Cidera janji dalam perjanjian kredit jaminan fidusia. Jurnal Transparansi Hukum, 4(1), 62-76.

Sriono. (2019). Tanggung jawab pemberi fidusia terhadap benda jaminan fidusia dalam perjanjian kredit. Jurnal Ilmiah Advokasi, 7(2), 149-159.

Suharto, R. (2017). Problematika akta jaminan fidusia (suatu studi tentang akta jaminan fidusia setelah berlakunya sistem pendaftaran fidusia secara online). Diponegoro Private Law Review, 1(1), 66-73.

Tobing, M. (2013, 11 April). Polisi tahan petinggi empat multifinance. Kontan.co.id. https://keuangan. kontan.co.id/news/polisi-tahan-petinggi-empatmultifinance

Ulum, M. (2013, 12 April). Penyelewengan dana; Polisi selidiki 17 multifinance. Kabar24. https:// kabar24.bisnis.com/read/20130412/16/8075/ penyelewengan-dana-polisi-selidiki-17-multifinance

Winarno, J. (2013). Perlindungan hukum bagi kreditur pada perjanjian jaminan fidusia. Jurnal Independent, 1(1), 44-55. https://doi.org/10.30736/ji.v1i1.5. 